\title{
Canine GM1-Gangliosidosis
}

National Cancer Institute

\section{Source}

National Cancer Institute. Canine GM1-Gangliosidosis. NCI Thesaurus. Code C129034.

GM1-g ang liosidosis that occurs in dogs, caused by mutation(s) in the GLB1 gene, encoding beta-galactosidase. 